This is an author produced version of a paper published in Medicine, Health Care and Philosophy. This paper has been peer-reviewed but does not include the final publisher proof-corrections or journal pagination.

Citation for the published paper:

Nilstun T, Hermeren G.

"Human tissue samples and ethics : - attitudes of the general public in sweden to biobank research."

Medicine, Health Care and Philosophy, 2006, Vol: 9, Issue: 1, pp. 81-6. http://dx.doi.org/10.1007/s11019-005-7984-4

Access to the published version may require journal subscription.

Published with permission from: Springer 


\section{Human tissue samples and ethics}

- attitudes of the general public in Sweden to biobank research

Tore Nilstun, professor

Göran Hermerén, professor

Both from the Department of Medical Ethics, Lund University, SE-222 22 LUND, Sweden

Number of words in text: 3237 (summary, 3 tables and 17 references are not included)

Number of words in summary: 205

\section{Correspondence to:}

Tore Nilstun

Dept of Medical Ethics

University of Lund

SE-222 22 Lund, Sweden

Phone +46462221282

Fax +46462221285

E-Mail: Tore.Nilstun@medetik.lu.se 


\title{
Human tissue samples and ethics
}

- attitudes of the general public in Sweden to biobank research

\begin{abstract}
- Purpose To survey the attitudes of the general public in Sweden to biobank research and to discuss the findings in the light of some well-known ethical principles.
\end{abstract}

- Methods A questionnaire was used to survey the opinions of the general public in Sweden, and an ethical analysis (using the principles of autonomy, non-maleficence, beneficence and justice) was performed to discuss the possible conditions of such research.

- Findings Between 3 and $9 \%$ answered that they did not want their samples to be collected and stored in a biobank. Many respondents required information about the purpose of the research and wanted to be able to consent or refuse. About one third of the respondents said they would have answered differently if financial gain was involved and those who commented indicated a more negative attitude. The principle of autonomy maintains that the right to self-determination should be respected, and the principles of non-maleficence and beneficence that the probable harms and benefits resulting from a particular project by using samples from a biobank should be balanced. The general public disagree about how these principles are to be balanced.

- Interpretation In the light of the findings different interpretations of the situation as well as possible alternatives are discussed in this paper.

Key words: autonomy, beneficence, biobank, research, non-maleficence, 
Basically, a biobank is a collection of a certain size of human tissue samples, stored for a certain time, for research and/or health care purposes. Biobanks give rise to ethical conflicts, i.e. situations where (at the same time) an agent ought to adopt each of two alternatives separately but cannot adopt both together (Sinnott-Armstrong, 1988, p. 29). On the one hand, biobanks offer an important opportunity for basic as well as applied research. They also have considerable commercial interest for companies in the area of personalised medicine and pharmacogenomics. On the other hand, biobanks contain personal information that could be very sensitive, especially for vulnerable individuals. Thus, a way has to be found to balance and weigh these considerations against each other, for example, to promote the health of the population and respect the right of individual self-determination. But what set of value premises are be used and which premise is most important?

The purpose of this article is twofold. First, to present the opinions of the general public in Sweden about the type of information and consent they think is desirable or required in order to allow research on human tissue samples. Second, based on the results of this survey, and given the four value premises of autonomy, non-malefiecence, beneficence and justice, to show the limits of this approach in stating the conditions for collecting, processing, storing, and accessing such samples.

To avoid misunderstanding it should be stressed that in this study we focus on the conditions for collecting human tissue samples in biobanks and on the conditions for carrying out research on these samples. Thus, we will not discuss the conditions for collecting, processing and storing such tissue samples for health care purposes. This would require a separate study, though we are aware that samples stored for health care purposes are sometimes used also for research, and that the distinction between research, evaluation, quality assurance, follow up, and so forth, are not always crystal clear.

\section{Method}

If a survey is to be carried out in a scientifically acceptable way, and so that the results could be generalised, several conditions have to be met. First, the questionnaire has to use a correct, comprehensible and realistic description of the conditions under which tissue samples are collected, stored and used for various purposes. Second, the questionnaires have to be tried and tested on different groups, and modified if necessary. Third, the questionnaire should be sent out to a randomised selection of respondents, who have to answer truthfully. 
Earlier versions of the questionnaire used in this study have been tested on samples from the general public, medical students, nurse students and researchers. We received more than 300 answers. The results showed that only a few persons were totally negative to such research, they differed as to the information and consent required, and many refused to have their tissue samples stored in commercial biobanks. The final version of the questionnaire was based on these results and the many comments to the test questionnaires. We asked three questions about the background of the respondents (year of birth, sex, education) and two questions about their experiences of health care and research respectively. Then we asked about their attitudes to collecting and storing tissue samples in biobanks and about the use of stored samples for a new purpose. We also asked whether financial gain, or if the research was done after their death, would play any role for their answers to the previous questions. All questions are indicated in the tables below.

The study population was identified via 2000 randomly selected addresses of persons in the age group 18-75 years and living in Sweden bought from Sema InfoData AB. Since the questions were in Swedish, we did not expect any answers from persons who did not write Swedish.

By answering and returning the respondents indicated that they agreed to participate in the study. One reminder was sent out. The questionnaire was anonymous. Thus a reminder was sent out to everyone. This procedure was explained in a letter to the informants.

The protocol, including the questionnaire, was sent to the research ethics committees (RECs) in Sweden. They all gave their approval (Lund 165-03, Göteborg M 038-03. Stockholm 03-142, Linköping 03-108, Umeå 03-103, Uppsala 03-146, and Örebro $115 / 03)$.

\section{Results}

Of the 2000 questionnaires originally sent out 926 were returned more or less completely answered. Only 10 envelopes were returned (because the address was unknown). Thus the response rate was $47 \%$ (Table 1 ).

Considering the proportion of men and women in Sweden, known facts about access to higher education in this country, as well as experience of health care and research, it would seem that the sample is fairly representative of the Swedish population. 


\section{Collecting and storing human tissue samples}

The participants' attitudes to collecting and storing human tissue samples in biobanks are shown in Table 2.

On average the older participants $(\geq 1954)$ were more negative to collecting and storing human tissue samples than the younger $(<1954)$. But as many as $9 \%$ with only basic education answered that they did not want their samples to be collected and stored compared to $3 \%$ of people with university education. Many respondents in all three educational groups required information and consent for research on human tissues collected in biobanks (basic 34, gymnasium 47 and university $47 \%$ respectively). Interestingly enough, people with university education, who might be expected to be more positive to research than others and to know more than others about the conditions under which research is carried out, were more negative or restrictive than other categories to research. They did not just want to be informed about the purpose of research, they also wanted to have the opportunity to say no - to consent as well as to refuse.

About one third of the respondents said they would have answered differently if the collecting and storing of human tissue samples in a biobank were done for financial gain. The by far most common comment was that it is particularly important to know what the tissue samples are to be used for, if the research is commercial and is carried out in order to make financial profit.

Some respondents were opposed to the idea of commercialisation of such research. In their view, only public non-profit institutions should own and be responsible for biobanks. Still others stressed that even if biobanks will make financial gains possible, this should not limit the use of the results for patients as to diagnostics and treatments. A few also wanted part of the profit (if any).

\section{Using human tissue samples for a new purpose}

By the expression "new purpose" is meant that the aim of the new research differs from the one earlier approved by the REC. Excluding those who answered that their human tissue 
samples should not be collected and stored in biobanks, Table 3 show the attitudes to research with a new purpose carried out on earlier collected and stored tissue samples.

There is no difference in attitudes between the sexes, but older participants ( $\geq 1954$ ) want more information about the new purpose of research before the stored human tissue samples are used than the younger (54 and $29 \%$ respectively). As with collecting and storing tissues in biobanks, many respondents in all three educational groups required information and consent for research with a new purpose (basic 30, gymnasium 46 and university $46 \%$ respectively).

We also asked hypothetically, what if the respondent was dead at the time when their samples were to be used for research with a new purpose. A little more than $5 \%$ answered that this would influence their answer. Most of those who commented on this question said that the agreement already made would be valid even after their death. Some wanted the relatives to decide or the samples to be destroyed. A few seemed to have misunderstood the question: when they are dead they cannot be asked.

The results of this study differ in at least one interesting way from our earlier pilot study. Fewer respondents in this study (the general public) than in the pilot study (mostly people with academic education) answered that they wanted to be informed about the new purpose with the biobank (42 and $51 \%$ respectively). However, when the research was carried out for commercial purposes about $30 \%$ of the respondents in both studies commented that such information was especially important. But by and large the results of the two studies point in the same direction.

\section{Facts and values}

In our study the attrition rate was very high (53\%). In a similar survey done in the north of Sweden the response rate was about $95 \%$ (Stegmayr and Asplund, 2002). This difference could be explained (at least partly) by differences in target group. In our study the questionnaire was sent to a random sample of the Swedish population, while in the latter study the questionnaire was only sent to those who already had donated biological samples. It should also be remembered that there might well have been an unknown number of people who did not understand or speak Swedish among the randomly chosen respondents. If roughly $10 \%$ of the inhabitants in Sweden are recent immigrants, we should expect a similar figure in 
the randomly chosen sample, roughly 200 persons. However, the high attrition rate in our study makes a margin of error $\pm 15 \%$ justified.

Besides these uncertainties, there are other problems. The most important is that given certain facts, different value premises may justify different recommendations (Nilstun, Melltorp and Hermerén, 2000; Nilstun and Sjökvist, 2001). For instance, if the ethical theory of Immanuel Kant is used as a value premise, the reaction to these surveys might be "So what?'. The categorical imperative in Kant's ethics will be decisive (Kant, 1785: chap. 2). Even if the majority of the population in a democratic country were in favour of racism, this cannot tell us what is right or wrong from a Kantian moral point of view. Another candidate for those who want to draw normative conclusions from surveys might be the preference utilitarianism advocated by Peter Singer. According to this theory, when faced by a choice between two actions, we ought to "give equal weight in our moral deliberations to the like interests of all those affected by our actions" (Singer, 1979: chap. 1). "Maximise the satisfaction of interests" becomes the key formula.

In this paper we will use as a starting point the well-known four principles of Beauchamp and Childress to see what normative conclusions, if any, can be drawn from these findings. The principles state the requirement of autonomy, non-maleficence, beneficence and justice, and are often used in medical ethics (Beauchamp and Childress, 2001; Gillon, 1994). The authors maintain far-reaching claims for application of these principles, and we wanted to test their utility.

\section{A model for identification and analysis of ethical conflicts}

We will use a simple model for identification and analysis of the ethical conflicts containing two different dimensions: the first denotes the affected persons and the other the relevant ethical principles (Nilstun, 1990).

The application of the model to a problematic situation requires an identification of persons involved, formulation of ethical principles, an assessment of ethical benefits and costs, and then finally a weighing of these benefits and costs.

The first task is thus to identify those affected or considered to be so in the public debate (Hermerén, 1999). The most important ones are the donating persons, the general public, the involved health care professionals, and the sponsor. In the Swedish legal system (and in many other systems) the donating persons are given the authority to make their own 
decisions, but the preferences of the general public might be a limiting condition. The health care professionals are involved (sometimes as researchers, sometimes because they have to explain the desirability to the participants of storing their samples in a biobank) and finally the (public or private) sponsor. The second task is to identify the value premises. A combination of the four groups of persons with the four ethical principles results in a matrix table, a checklist with 16 cells.

\section{Different value premises}

The third task is to identify ethical benefits and costs for the persons involved. The two expressions "ethical benefits" and "ethical costs" are used in a fairly broad sense. Anything from the perspectives of autonomy, non-maleficence, beneficence and justice that could reasonably make a change for the better for someone is considered an ethical benefit. On the other hand, an ethical cost is everything that could reasonably be considered harmful. The principle of autonomy has its basis in the liberal tradition. It requires that those who are capable of deliberation about their personal goals should be treated with respect for their capacity for self-determination. According to the liberal theories, as expressed for instance by the British philosopher John Locke, coercion may only be used to prevent and punish physical harm, theft, and fraud, and to enforce contract (Locke, 1690). Otherwise the right to self-determination should be respected. Thus, any potential donors should be informed about the purpose of the biobank and freely accept or refuse to participate.

But the democratic principle, implying that the opinion of the majority should be respected, may occasionally clash with the principle of autonomy. Thus, majority opinions could decide how to regulate the collection, storing and use of human tissue samples. The health care professionals main task would then be to explain the requirements of the law and the donor would have to accept.

The principle of non-maleficence states the ethical obligation to minimise possible harms. This means that all persons have a moral obligation not to harm anybody. Especially, those who are dependent or vulnerable should be provided security against harm (Beauchamp and Childress, 2001).

The principle of beneficence states the ethical obligation to maximise possible benefits. This means that all men have a moral obligation to prevent suffering, to remove suffering and, if practically possible, to promote wellbeing. To harm can only be justified when the 
aim is to make a greater good - first and foremost for those exposed to any risk (Mill, 1861). The probable harms and benefits resulting from a particular project by using samples from a biobank should be balanced. This could be a task for RECs.

The principle of justice is the most controversial to define in this context. It is inspired by discussions related to the distribution of goods and burdens and states the ethical obligation not to discriminate and to show solidarity with those who cannot satisfy their own needs (Hermerén, 2000). Though most people seem to agree that justice is a requirement in this context, any attempt to specify the material rule to be followed becomes controversial. Is it to each person an equal share, according to need, effort, contribution, merit or the freemarket exchanges? One of those who have addressed this issue, John Rawls, accepts positive discrimination if it gives the greatest benefit to those worse off (Rawls, 1971: pp. 302f). Again RECs might have to decide whether or not the relevant justice requirements are satisfied.

\section{Weighing benefits and costs}

In our study some respondents, $6 \%$, did not want their biological samples to be collected and stored in biobanks, but the generalised number could be somewhat lager or smaller. The only way to satisfy these persons is to have some mechanism for opting out, for instance informing the individual about the biobank and asking permission to store the sample. If an individual refuses, no sample will be stored. One thing that certainly is clear from the present study is that most respondents want to know whether or not the biological tissue samples will be stored and used for research, and many also want to be asked for consent.

What if the samples are to be used for research with a new purpose? If the only requirement is that the donor is informed that the samples will be used for research, the new purpose is no problem. However, many people want to be informed about the new purpose of the research. A new purpose (often more than ten years later) would, if their requirement is to be satisfied, need a new contact to inform them and to give them the opportunity to consent or to refuse. This would, as a rule, result in high costs and high attrition rate.

There seems to be several different ways to solve this problem assuming the REC approve of the project. One could pay the extra costs related to finding addresses and accepting a 
higher attrition rate or one could simply abstain from the new research project. But the situation is different, if no information is required about the new research purpose. In the latter situation the potential donor will only be informed at collection that the samples will be stored in a biobank and used for research (with or without economic gain).

\section{Concluding remarks}

Based on our questionnaire and analysis it is possible to draw a number of more general conclusions. The four-principles approach recommended by Beauchamp and Childress is far from solving the ethical problems raised by biobanks. This is due to the difficulties, especially in problems involving societal issues, of getting the agents and stakeholders to agree on (a) the interpretation and specification of these four principles, and (b) on how they should be balanced against each other when they clash, as they sometimes do in this case. The remaining ethical conflict between the demand for informed consent and the demand for social utility requires other approaches such as those suggested by the Nuffield Council on Bioethics Human Tissue (1995); European Group on Ethics in Science and New Technologies (1998); and Nationaler Ethikrat (2004).

The results of this study, as well as of our earlier one, also undermine general statements of a sort that too frequently have been used in the public debates about the conditions under which biobanks may be used for research, in particular statements to the effect that nobody or everyone

- wants that their tissue samples to be thrown away and not to be used for research or for future health care purposes (quality control, checking of diagnoses etc);

- wants to be informed that their tissue samples will be stored in a biobank;

- wants to be given an opportunity to consent (or refuse) that the samples they have donated are used for research;

- thinks that a condition for consent is that they are informed about what type of research the donated tissues are to be used for;

- thinks that this is so in particular when earlier collected tissues are to be used for a new research purpose;

- thinks that the research ethics committees should decide what is required in each particular case concerning information and consent; 
- thinks that it matters for their decision of this research on human tissue samples is carried out for financial gain.

In fact, as to the comments to the questions, the by far most common one was that those who had donated their tissue samples had done so for altruistic purposes. In other words, the purpose of their donation was to further research intended to improve medical knowledge and ultimately diagnosis, therapy and follow up. If the research was carried out for financial purposes, then information and consent were all the more important. 
Table 1: Respondents' background: age, education and experience

\begin{tabular}{lrr}
\hline & $\begin{array}{r}\text { Males } \\
(\mathrm{n}=405-414)\end{array}$ & $\begin{array}{r}\text { Females } \\
(\mathrm{n}=494-506)\end{array}$ \\
\hline Year of birth (mean/SD) & $1953 / 16$ & $1956 / 15$ \\
Education, B/Gy/Un* (\%) & $31 / 38 / 31$ & $23 / 39 / 38$ \\
Experience of health care (\%) & 9 & 32 \\
Experience of research (\%) & 3 & 2 \\
\hline
\end{tabular}

* Education (including non-finished): B = basic, Gy = gymnasium, and Un = university. 
Table 2: Attitudes to collecting and storing human tissue samples in biobanks where the donor can be traced (\%)

\begin{tabular}{lrr}
\hline & $\begin{array}{r}\text { Males } \\
(\mathrm{n}=407)\end{array}$ & $\begin{array}{r}\text { Females } \\
(\mathrm{n}=497)\end{array}$ \\
\hline $\begin{array}{l}\text { 1. I don't want my samples to be used in research } \\
\begin{array}{l}\text { 2. I want to be informed and asked if I accept that } \\
\text { my samples be used in research, and I also } \\
\text { want to be informed about the purpose }\end{array}\end{array}$ & 32 \\
$\begin{array}{l}\text { 3. I want to be informed and asked if I accept that } \\
\text { my samples be used in research, but I don't } \\
\text { need to be informed about the purpose } \\
\begin{array}{l}\text { 4. REC should decide whether or not information } \\
\text { and consent is required }\end{array}\end{array}$ & 10 & 39 \\
$\begin{array}{l}\text { 5. Information and consent is not required } \\
\text { Aritmetic mean (range 1-5)* }\end{array}$ & 16 & 36 \\
\hline
\end{tabular}

* 1 = I don't want my samples to be used in research, $\ldots, 5=$ Information and consent not required 
Table 3: Attitudes to the use of collected samples in research with a new purpose where the donor can be traced (\%)

\begin{tabular}{lcc}
\hline & $\begin{array}{c}\text { Males } \\
(\mathrm{n}=391)\end{array}$ & $\begin{array}{c}\text { Females } \\
(\mathrm{n}=469)\end{array}$ \\
\hline $\begin{array}{l}\text { 1. I don't want collected samples to be used in } \\
\text { research with a new purpose }\end{array}$ & 39 \\
$\begin{array}{l}\text { 2. I want to be informed and asked if I accept that } \\
\text { collected samples be used in research with a } \\
\text { new purpose }\end{array}$ & 22 & 34 \\
$\begin{array}{l}\text { 3. REC should decide whether or not information } \\
\text { and consent is required }\end{array}$ & 35 \\
$\begin{array}{l}\text { 4. Information and consent is not required } \\
\text { Aritmetic mean (range 1-4)* }\end{array}$ & 2.88 & 2.87 \\
\hline * 1 = I don't want my samples to be used in research, ... $5=$ Information and consent not required
\end{tabular}

* 1 = I don't want my samples to be used in research, $\ldots, 5=$ Information and consent not required 


\section{References}

Beauchamp, T.L. and J.F. Childress: 2001, Principles of Biomedical Ethics (5th edition). Oxford: Oxford University Press (first published 1989).

European Group on Ethics in Science and New Technologies: 1998, Ethical Aspects of Human Tissue Banking. Opinion No 11, Brussels.

Gillon, R. ed.: 1994, Principles of Health Care Ethics. Chichester: John Wiley \& Sons.

Hermerén, G.: 1999, 'Neonatal screening: ethical aspects', Acta Paediatrica, Supp 432, 99103.

Hermerén, G.: 2000, 'Priorities and research allocation: Problems, principles and procedure', In: L. Vahlne Lotterhäll (ed.). Health care priorities. Ethical, legal and economic perspectives. Stockholm: Santérus, pp. 11-30.

Kant, I.: 1785, Grundlegung zur Metaphysik der Sitten. Hamburg.

Locke, J.: 1690, An essay concerning human understanding. London.

Mill, J.S.: 1861, Utilitarianism. London.

Nationaler Ethikrat: 2004, Biobanken für Forschung. Stellungsnahme. Berlin.

Nilstun, T.: 1990, 'Public health measures with HIV infection. A model for identification and analysis of ethical conflicts', In: P. Allebeck and B. Jansson (eds.), Ethics in medicine: Individual integrity versus demands of society. New York: Raven Press, pp. 203-213.

Nilstun, T., G. Melltorp and G. Hermerén: 2000, 'Surveys on attitudes to active euthanasia: to draw normative conclusions is problematic' Scandinavian Journal of Public Health 28, 111-116.

Nilstun, T. and P. Sjökvist: 2001, 'From fact to recommendation: explicit value premises make the conclusions more convincing', Journal of internal medicine 249, 121-125.

Nuffield Council on Bioethics: 1995, Human Tissue: Ethical and Legal Issues. London.

Rawls, J.: 1971, A theory of justice. London, Oxford, New York: Oxford University Press.

Singer, P.: 1979, Practical Ethics. Cambridge: Cambridge University Press.

Sinnott-Armstrong, W.: 1988, Moral Dilemmas. Oxford: Basil Blackwell. 
Stegmayr, B. and K. Asplund: 2002, 'Informed consent for genetic research on blood stored for more than a decade: a population based study', British Medical Journal 325, 634635. 